\title{
Międzynarodowa konferencja naukowa: „Myśl edukacyjna w Galicji 1772-1918. Ciąglość i zmiana” Rzeszów 27-29 IV 1995
}

W dniach 27-29 IV 1995 roku odbyła się w Wyższej Szkole Pedagogicznej w Rzeszowie Międzynarodowa Konferencja Naukowa na temat: „Myśl edukacyjna w Galicji 1772-1918. Ciagłość i zmiana". Była to już to trzecia konferencja naukowa poświęcona problemom kultury i oświaty w Galicji. Pierwsza sesja pt. „Stan i potrzeby badań nad dziejami oświaty w Galicji" odbyła się w 1986 roku w Lańcucie. W 1989 roku ukazały się materiały pokonferencyjne pt. „Z dziejów oświaty w Galicji”, Rzeszów 1989. Ponadto na konferencji wysunięto postulat opracowania bibliografii do dziejów oświaty w Galicji. Bibliografia taka została opracowana przez zespół pracowników Zakładu Historii Wychowania Instytutu Pedagogiki w WSP w Rzeszowie przy współpracy WSP w Kielcach i wydana w 1992 r.

W 1992 roku z inicjatywy JM Rektora prof. K. Sowy zorganizowano międzynarodowa konferencje na temat: „Galicja i jej dziedzictwo", w ramach której problemy nauki i kultury były przedmiotem obrad odrębnej sekcji. Zgromadziła ona historyków wychowania $z$ różnych ośrodków uniwersyteckich w kraju i za granica. Owocem tego spotkania jest t. 3 z serii wydawniczej „Galicja i jej dziedzictwo”, zatytulowany „Nauka i oświata” (pod red. A. Meissnera i J. Wyrozumskiego, Rzeszów 1995).

Kolejna konferencję z tej serii zorganizowano z inicjatywy prof. A. Meissnera i prof. $\mathrm{Cz}$ Majorka. Poświęcona została myśli edukacyjnej w Galicji na tle innych krajów monarchii austriackiej. Podstawowym celem konferencji była próba bliższego określenia pluralistycznego charakteru myśli edukacyjnej XIX i początków XX wieku, jej genezy i roli, jaką odegrała w rozwoju oświaty. Ponadto podjęto odpowiedzi na pytanie: jakimi drogami myśl edukacyjna docierała do Galicji? oraz jakie były najważniejsze nośniki teorii pedagogicznych?

W konferencji wzięli udział pracownicy naukowi z Polski, Slowacji i Ukrainy. Uczelnie krajowe reprezentowali przedstawiciele następujących ośrodków: Uniwersytetu Jagiellońskiego (prof. T. Aleksander, dr B. Luczyńska), Uniwersytetu Marii Curie-Skłodowskiej (dr B. Jaśkiewicz), Uniwersytetu im. A. Mickiewicza w Poznaniu (prof. J. Hellwig, dr W. Jamrożek), Uniwersytetu Opolskiego (prof. S. Gawlik), Uniwersytetu Śląskiego (dr G. Kempa, dr A. Stopińska-Pajak), Uniwersytetu im. Mikołaja Kopernika (dr hab. W. Wojdyło, dr M. Strzelecki), Uniwersytetu Wroctawskiego (dr A. Ladyżyński, dr R. Stępień, dr J. Szablicka-Żak, dr S. Walasek) oraz WSP w Bydgoszczy (dr K. Jakubiak), WSP w Częstochowie (dr K. Rędziński), WSP w Kielcach (mgr M. Pękowska); WSP w Krakowie (dr A. Kliš, dr W. Marmon, dr J. Ryś) i WSP w Rzeszowie (dr A. Horbowski, mgr A. Krzanowski, dr J. Potoczny, mgr M. Polańska, dr Z. Sokól, dr K. Szmyd, dr W. Szulakiewicz). Uczelnie zagraniczne reprezentowali pracownicy naukowi Uniwersytetu w Bratysławie, Uniwersytetu w Koszycach, Uniwersytetu Lwowskiego, Uniwersytetu Wołyńskiego i Instytutu Pedagogicznego w Drohobyczu.

Podczas 3-dniowych obrad wygłoszono 50 referatów w trzech sekcjach. W sekcji I pt. „Myśl edukacyjna" problematyka wygloszonych referatów dotyczyła następujących zagadnieñ: początków kształtowania się pedagogiki jako nauki ze wskazaniem różnych nurtów w dziejach jej rozwoju oraz wpływów pedagogiki zachodniej; relacji polityka a pedagogika, a także problemów metodologii badań historyczno-oświatowych, w szczególności badań nad myślą pedagogiczna.

"Czasopiśmiennictwo pedagogiczne" to główna problematyka obrad sekcji II. Wygloszone w tej sekcji referaty traktowały o czasopismach pedagogicznych oraz problemach oświatowych prezentowanych na lamach tych czasopism a także czasopism młodzieżowych, kobiecych czy urzędowych. W szczególności skoncentrowano się na zagadnieniach zawartości czasopism pedagogicznych Galicji, Austrii, Słowacji i Ukrainy oraz roli czasopiśmiennictwa pedagogicznego 
w rozwoju myśli pedagogicznej. Z kolei w sekcji III pt. „Oświata i szkolnictwo” dyskutowano głównie nad problemami organizacji i funkcjonowania szkolnictwa różnych szczebli, rolą towarzystw oświatowych w rozwoju szkolnictwa. Zaprezentowano także sylwetki wybitnych pedagogów i działaczy oświatowych.

Przedstawiony przez referentów materiał dał podstawy do owocnej dyskusji, w wyniku której wysunięto wiele postulatów badawczych, wskazujących na potrzebę zorganizowania kolejnej konferencji z serii „Galicja i jej dziedzictwo”.

Konferencji towarzyszył kiermasz wydawnictw książowych, podczas którego rozprowadzano m.in. wydawnictwa $z$ poprzednich sesji naukowych.

Madyslawa Szulakiewicz

\section{„Nauczanie w Polsce średniowiecznej i wczesnonowożytnej” Mąchocice-Ameliówka kolo Kielc, 18-20 maja 1995 r.}

W dniach od 18 do 20 maja 1995 odbyła się w Mąchocicach-Ameliówce koło Kielc konferencja naukowa poświęcona nauczaniu w Polsce w średniowieczu i w czasach nowożytnych. Sesję tą zorganizował Instytut Historii Wyższej Szkoły Pedagogicznej w Kielcach, a otwarcia obrad dokonal dyrektor Instytutu Historii WSP prof. Adam Massalski.

W pierwszym đniu konferencji (18.05) wygloszono 6 referatów i komunikatów. Jako pierwsza zabrała głos prof. Jadwiga Krzyżaniakowa (Poznań), która przedstawila referat „W kręgu kultury uniwersyteckiej - nauczyciele i uczniowien. Kolejny referent, prof. Eugeniusz Wiśniowski (Lublin), omówił siéc szkół parafialnych na przelomie XV i XVI wieku. W dalszej części obrad odczytano referat, nieobecnego na sali, prof. Jacka Wiesiołowskiego (Poznań), poświęcony szkolnictwu wielkopolskiemu końca średniowiecza. Następnie głos zabrał dr Jan Ryś (Kraków), który scharakteryzował rolę szkół kolegiackich w nauczaniu kościelnym w okresie średniowiecza.

Następnymi referentami byli: mgr Adam Fijalkowski (Warszawa), który zajął się zagadnieniem szkolnictwa parafialnego na Mazowszu w XV-XVI wieku oraz dr Jan Krukowski (Kraków), ten ostatni zaprezentował referat „Nauczyciele krakowskich szkół parafialnych w XVII wieku". Wystąpienie dr H. Patkowej (Praga), poświęcone było zagadnieniu bractw w średniowiecznych Czechach. Prof. Stanisław Bylina (Warszawa) omówił katechezę ludności wiejskiej w późnośredniowiecznej Polsce, a mgr Wlodzimierz Batóg (Kielce) zaprezentował komunikat na temat wędrownego kaznodziejstwa w „Opowieściach kanterberyjskich” Geoffreya Chaucera. Dr Krzysztof Bracha (Kielce) przedstawił referat „Pierwsze przykazanie w katechezie późnośredniowiecznej w świetle Komentarzy do Dekalogu". Pierwszy dzień obrad zakończył komunikat mgr Beaty Wojciechowskiej (Kielce), poświęcony treściom edukacyjnym jasełek w XV i w pierwszej połowie XVI wieku.

Drugi dzień konferencji otworzyło wystąpienie prof. Edwarda Potkowskiego (Warszawa), który przedstawił szkołę średniowieczną jako ośrodek kopiowania tekstów edukacyjnych.

Po nim głos zabrał prof. Ryszard Kiersnowski (Warszawa); jego referat ukazywał wartości dydaktyczne w numizmatyce średniowiecznej. Prof. Alicja Karłowska-Kamzowa (Poznań) omówila ilustracje traktatu Jakuba de Cessolis „Księga figur szachowych” jako narzędzie nauczania od połowy XIV do poczatku XVI wieku. Referat dr Małgorzaty Wilskiej (Warszawa) pokazał edukacje dworską, jej sposoby i instrumenty nauczania na przykładzie dworu jagiellońskiego. Prof. Wojciech Iwańczak (Kielce) zajał się w swoim wystąpieniu problemem wychowania rycerskiego w średniowiecznych Czechach, a mgr Beata Janowska (Warszawa) przedstawiła edukację dziewcząt w Polsce XV wieku. Następnie glos zabrał dr Marian Chachaj (Lublin), który zaprezentował referat „Wykształcenie a kariera w Polsce XVI wieku”. Wystąpienie prof. Henryka Gmiterka 